\title{
Second homes in the Slovenian Alps with special emphasis on the Municipality of Bovec
}

\author{
Vikendice u slovenskim Alpama s posebnim naglaskom na \\ općinu Bovec
}

In the past decades, second homes have caused important transformations in the morphology of traditional village-based settlements in many mountain areas. Such changes are particularly evident in the intense concentration of these buildings in some settlements and can occur in the form of multi-apartment recreational complexes, intentionally designed for second home users. This paper analyses spatial development of registered second homes in the municipality of Bovec, Slovenia, thus contributing to understanding the specifics of this phenomenon in the wider Alpine region, as well as in other mountainous regions. The authors examine the selected characteristics of the municipal second home housing stock (location, age, intensity of the phenomenon) and present the data in detailed cartographic representations. The analysed data were obtained from the statistical censuses and the Real Estate Registry of the Surveying and Mapping Authority of the Republic of Slovenia.

Key words: second homes, mountain areas, spatial development, Municipality of Bovec, the Alps, Slovenia
Proteklih su desetljeća vikendice uzrokovale značajne transformacije u morfologiji tradicionalnih seoskih naselja u mnogim planinskim područjima. Te su promjene osobito vidljive u naglašenoj koncentraciji vikendica u formi kuća u ponekim naseljima, a mogu se javljati i u obliku višestambenih apartmanskih zgrada za odmor i rekreaciju. U ovom se radu analizira prostorni razvoj registriranih vikendica u slovenskoj općini Bovec, pridonoseći tako razumijevanju specifičnosti toga fenomena u širem alpskom području, ali i u drugim planinskim regijama. Autori proučavaju odabrana obilježja stambenoga fonda vikendica u općini (lokaciju, vrijeme izgradnje, intenzitet fenomena vikendaštva) i prezentiraju podatke pomoću detaljnih kartografskih prikaza. Analizirani podaci dobiveni su iz statističkih popisa stanovništva i Katastra nekretnina iz Geodetske uprave Republike Slovenije.

Ključne riječi: vikendice, planinska područja, prostorni razvoj, općina Bovec, Alpe, Slovenija 
HRVATSKI

GEOGRAFSKI

GLASNIK

81/1, 61-81 (2019.)

\section{Introduction}

The Alps are the most extensive and the highest mountain range system that lies entirely within $\mathrm{Eu}-$ rope, stretching across $1,200 \mathrm{~km}$ through eight countries (Austria, France, Germany, Italy, Liechtenstein, Monaco, Slovenia, and Switzerland). Because of rich natural resources, importance of transport corridors, and exceptional tourism potential, the Alps are exposed to a number of environmental and spatial pressures. Environmental conditions are additionally aggravated by the extremely dynamic terrain, which limits activities and settlement in specific areas. Spatial development is thus torn between the interests of the local population, the business community, transport experts, tourism providers, environmental protectionists, and others that seek opportunities in this attractive mountainous environment (Nared et al., 2015).

Demographic and economic changes in the $20^{\text {th }}$ century significantly influenced the spatial development of many mountain areas in the developed world and stimulated the construction of second homes. In addition to the Alpine region, Scandinavia must be mentioned within the European area. Regardless of the many similarities between the two areas, which comprise some of the most economically developed countries in the world, some differences in the process of development of second homes are clearly evident. The occurrence of second homes in the mountainous and rural areas of Scandinavia goes back several centuries. Nowhere in the world are second homes as widespread as in Scandinaviatoday they are a recognisable and inseparable part of the Scandinavian culture and cultural landscape. In the Alpine region it is generally difficult to find such a long tradition of second homes (although holiday dwellings that are over 150 years old are not uncommon in some established tourism areas), but they undoubtedly have played a prominent role in the spatial development of the area, particularly over the last few decades (Hall et al., 2008; Flognfeldt and Tjørve, 2013; Sonderegger and Bätzing, 2013).

In Slovenia, where the construction of second homes reached its peak in the 1980s, the concentration of such dwellings is high in established tourism destinations. According to the data obtained from
Uvod

Alpe su najprostraniji i najviši planinski sustav koji se u potpunosti nalazi u Europi i proteže u dužini većoj od $1200 \mathrm{~km}$ kroz osam država (Austrija, Francuska, Njemačka, Italija, Lihtenštajn, Monako, Slovenija i Švicarska). Alpe su izložene brojnim okolišnim i prostornim pritiscima zbog bogatih prirodnih resursa, važnosti prometnih koridora i iznimnih turističkih potencijala. Okolišni uvjeti dodatno su pogoršani ekstremno dinamičkim terenom koji ograničava aktivnosti i naseljavanje u određenim područjima. Prostorni je razvoj tako rastrgan između interesa lokalnoga stanovništva, poslovne zajednice, stručnjaka za promet, pružatelja turističkih usluga, osoba koje se zalažu za zaštitu okoliša i drugih koji u tom privlačnom planinskom okruženju traže svoju priliku (Nared i dr., 2015).

Demografske i gospodarske promjene u 20 . stoljeću značajno su utjecale na prostorni razvoj mnogih planinskih područja u razvijenom svijetu i potaknule izgradnju vikendica. U ovom kontekstu na području Europe uz regiju Alpa valja spomenuti i Skandinaviju. Bez obzira na mnoge sličnosti između tih dvaju područja, koja uključuju neke od gospodarski najrazvijenijih zemalja svijeta, jasno su vidljive određene razlike u procesu razvoja vikendaštva. Pojava vikendaštva u planinskim i ruralnim područjima Skandinavije prisutna je već nekoliko stoljeća. Nigdje drugdje u svijetu vikendice nisu toliko raširena pojava kao u Skandinaviji - danas su one prepoznatljiv i neodvojiv dio skandinavske kulture i kulturnoga pejzaža. Općenito je u alpskoj regiji teško pronaći tako dugu tradiciju vikendaštva (premda u nekim turističkim destinacijama s dugom tradicijom vikendice starije od 150 godina nisu rijetkost) iako su one nesumnjivo odigrale važnu ulogu u prostornom razvoju područja, osobito posljednjih nekoliko desetljeća (Hall i dr., 2008; Flognfeldt i Tjørve, 2013; Sondereger i Bätzing, 2013).

U Sloveniji, gdje je izgradnja vikendica vrhunac dostigla 1980-ih, koncentracijom takvih objekata ističu se poznate turističke destinacije. Prema podacima dobivenima od Statističkoga ureda Republike Slovenije (u daljnjem tekstu: SORS) 
the Statistical Office of the Republic of Slovenia (hereinafter: SORS) and the Surveying and Mapping Authority of the Republic of Slovenia (hereinafter: SMARS), the mountain region of the Julian Alps in the north-western part of the country recorded the highest share of second homes in the municipal housing stock, as shown in Fig. 1. Here, three municipalities stood out in 2011: Bohinj (26.5\%); Kranjska Gora (24.5\%); and Bovec (23.5\%) (SORS, 2011a). The number of second homes in this region noticeably increased in the second half of the $20^{\text {th }}$ century (Koderman and Salmič 2013; Salmič and Koderman, 2013; Koderman, 2017), parallel to the rise of tourist and recreational activities.

After the reorganisation of the local government, the municipality of Bovec was founded in 1995, when it seceded from the former municipality of Tolmin. The municipality of Bovec is the fourth largest Slovenian municipality and as much as $79 \%$ of its surface lies in Triglav National Park (hereinafter: TNP) (Ordinance on the Municipal Spatial Plan of i Geodetske uprave Republike Slovenije (u daljnjem tekstu: SMARS) planinska regija Julijskih Alpa u sjeverozapadnom dijelu države zabilježila je najveći udio vikendica u općinskom stambenom fondu, kao što je prikazano na sl. 1. Prema udjelu vikendica u stambenom fondu 2011. godine istakle su se tri općine: Bohinj (26,5 \%), Kranjska Gora (24,5 \%) i Bovec (23,5 \%) (SORS, 2011a). Broj vikendica u ovoj se regiji zamjetno povećao u drugoj polovici 20. stoljeća (Koderman i Salmič, 2013; Salmič i Koderman, 2013; Koderman, 2017) usporedno s porastom turističkih i rekreacijskih aktivnosti.

Nakon reorganizacije lokalne uprave 1995. godine osnovana je općina Bovec izdvajanjem iz nekadašnje općine Tolmin. Općina Bovec površinom je četvrta najveća slovenska općina, a 79 \% njezine površine nalazi se u sklopu Nacionalnoga parka Triglav (dalje u tekstu: NPT) (Pravilnik o prostornom uređenju općine Bovec, 2008). U općini Bovec 2011. godine registrirana su 632 objek-

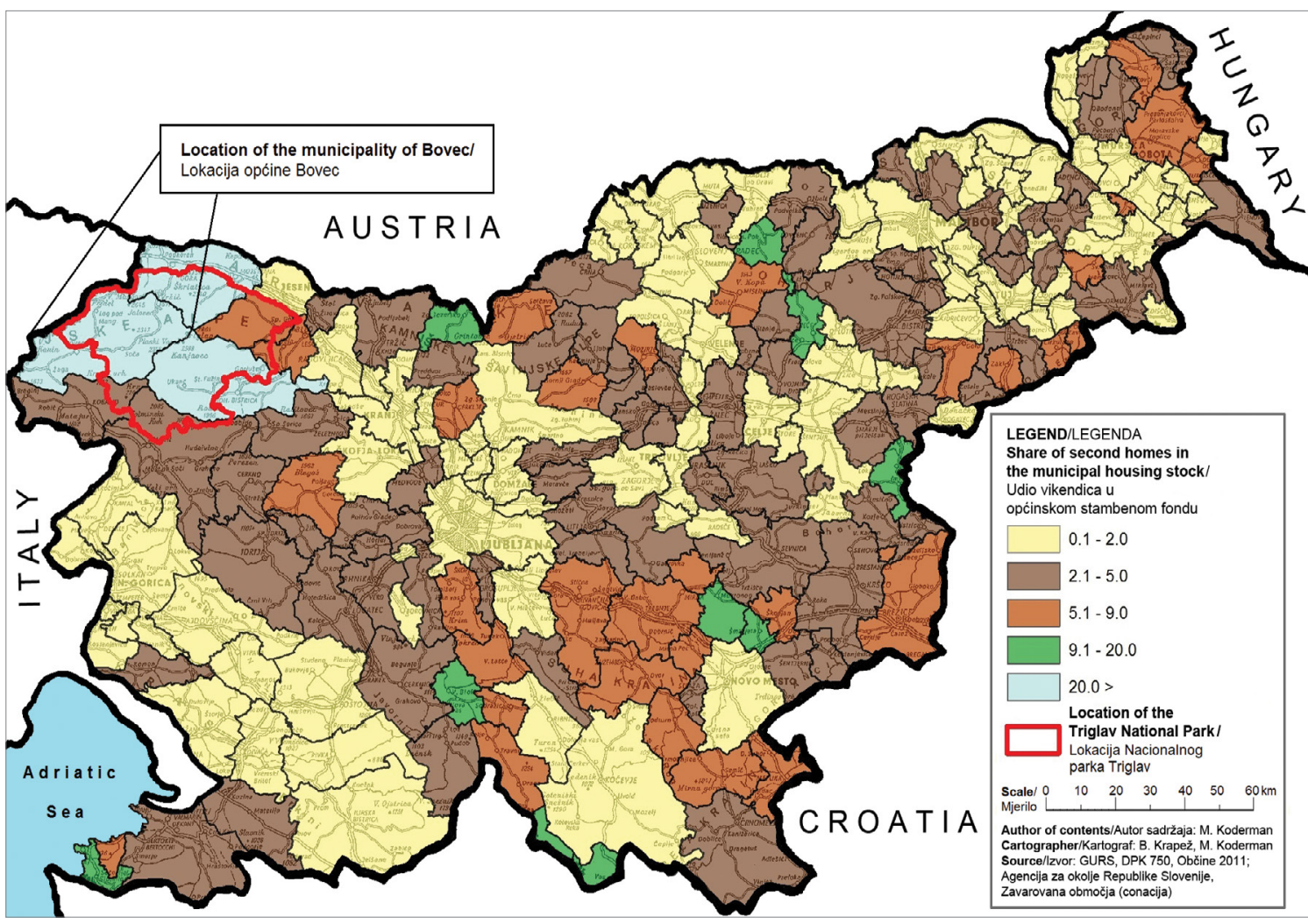

Fig. 1 Location of the municipality of Bovec and shares of second homes in the housing stock of Slovenian municipalities in 2011 SI. 1. Položaj općine Bovec i udio vikendica u stambenom fondu slovenskih općina 2011. godine 
HRVATSKI

GEOGRAFSKI

GLASNIK

81/1, 61-81 (2019.)
Bovec, 2008). With 632 buildings (out of 2,692) categorised as second homes, the municipality of Bovec was registered as third among all Slovene municipalities in 2011 regarding the share of second homes in the municipal housing stock (SORS, 2011a).

The main purpose of this study is to present the key features of the spatial distribution of second homes in the municipality of Bovec, while placing this phenomenon in the broader context of spatial development of similar settlements in the Alpine region.

\section{Second homes in mountain areas and in the municipality of Bovec in geographical discussions}

Spatial development of second homes in the mountain areas has received relatively minor attention in professional and scientific literature. When studying this phenomenon at the European level, mostly Scandinavian countries are highlighted, e.g. Norway. This is not a surprise, since the tradition of spending leisure time and holidays in second homes and second home ownership itself is deeply rooted in Scandinavian culture. Many authors, such as Hall and Müller (2004) and Hall et al. (2008) emphasise the significance of second homes in the Scandinavian (mountainous) landscape and their presence in traditional culture. They estimate that around 1.5 million such dwellings exist throughout Scandinavian countries, most of which are located in the coastal belt and mountain areas. In this region, there are over 24 million inhabitants and more than half of them have access to a second home.

"Second home culture" in the Alps does not have such long, rooted and widespread tradition, especially when compared to Scandinavia. Several authors have analysed general effects of second home development that are also evident in the mountainous areas of the Alps. As argued by Müller et al. (2004), the process of conversion of permanent homes to second homes in rural regions usually arises as a result of population and economic decline. This process has strongly characterised mountain landscapes and can therefore be found in Alpine regions, especially in geographically peripheral areas. ta za odmor i rekreaciju (od ukupno 2692 objekta u stambenom fondu), što je stavlja na treće mjesto među slovenskim općinama u pogledu udjela vikendica u općinskom stambenom fondu (SORS, 2011a).

Glavni je cilj ovoga istraživanja predstaviti osnovne značajke prostornoga razmještaja vikendica u općini Bovec, istovremeno smještajući taj fenomen u širi kontekst prostornoga razvoja sličnih naselja u alpskom prostoru.

\section{Vikendice u planinskim područjima i općini Bovec u geografskim raspravama}

Prostorni razvoj vikendaštva u planinskim područjima dobivao je razmjerno slabu pozornost u stručnoj i znanstvenoj literaturi. Prilikom proučavanja ovoga fenomena na europskoj razini ističu se većinom skandinavske zemlje, primjerice Norveška. To ne iznenađuje jer su tradicija provođenja slobodnoga vremena i godišnjega odmora u vikendicama te posjedovanje vikendice duboko ukorijenjeni u skandinavsku kulturu. Mnogi autori, primjerice Hall i Müller (2004) i Hall i dr. (2008), naglašavaju važnost vikendica u skandinavskom (planinskom) pejzažu i njihovu prisutnost u tradicionalnoj kulturi. Oni procjenjuju da u skandinavskim zemljama postoji oko 1,5 milijun kuća za odmor, od kojih se većina nalazi u obalnom pojasu i planinskim područjima. U Skandinaviji živi više od 24 milijuna ljudi, a više od polovine na raspolaganju ima vlastitu vikendicu.

„Kultura vikendice” u Alpama nema tako dugu, ukorijenjenu i raširenu tradiciju, posebice u usporedbi sa Skandinavijom. Veći je broj autora analizirao opće utjecaje razvoja vikendaštva koji su vidljivi i u planinskim područjima Alpa. Kao što navode Müller i dr. (2004), proces pretvorbe stambenoga fonda za stalno stanovanje $\mathrm{u}$ vikendice $\mathrm{u}$ ruralnim područjima obično se događa zbog smanjenja broja stanovništva i gospodarske aktivnosti. Taj je proces snažno obilježio planinski pejzaž, stoga se može pro- 
When analysing the spatial distribution of second homes in the Alpine region, one has to mention the work of Sonderegger and Bätzing (2013). Given the lack of statistical data and the fact that due to national tax policies many owners do not register their second home, they estimated that there were fewer than 2 million holiday dwellings in the region of the Alps in 2000 and 2012 (or 26\% of total housing stock). They pointed out obvious differences in the spatial distribution of second homes throughout the region-most of them were located in the western part of the Alps (especially in France and Italy, where the share of such homes in many municipalities exceeded $80 \%$ of total housing stock), and the least in the east (including Slovenia). The reasons for this can be found in the natural (relief) and cultural (legislation, state regulation) characteristics of individual countries. The authors identified Slovenia as a country where the number of second homes in the Alpine region has increased the most in the last two decades (according to their estimates there were around 40.000 of such dwellings in 2012). Among the key reasons for the proliferation of second homes in the Alps, they expose the fact that this is a traditional tourism area (with a growing number of tourists) where (in cases of some municipalities) emigration processes of the permanent population persists. Sonderegger and Bätzing did not focus more specifically on the spatial aspect and the specific effects of second homes in the Alpine space.

Over the past five decades, second homes in the Slovenian (Yugoslavian until 1991) part of the Alps were also studied by a number of geographical, architectural, and anthropological researchers. They focused mainly on the wider region of the eastern Julian Alps-the area that largely overlaps with TNP, which, due to its natural values, is an especially attractive and delicate environment for leisure activities. The largest number of studies dealt with the area of the contemporary municipality of Bohinj (Vojvoda, 1965; Kalan, 1983; Gosar, 1987; 1988; Bajuk Senčar, 2005; Koderman and Salmič, 2013); among the more interesting areas for exploring this phenomenon were the municipalities of Kranjska Gora (Gosar, 1988; Salmič and Koderman, 2013) and Bovec (Gosar, 1988; Vranješ, 2005; 2008). naći u alpskim regijama, posebice u geografski perifernim područjima.

Prilikom analize prostornoga razmještaja vikendica u alpskom području treba spomenuti rad Sondereggera i Bätzinga (2013). S obzirom na manjak statističkih podataka i činjenicu da, uslijed državne porezne politike, mnogi vlasnici ne registriraju svoje vikendice, autori procjenjuju da je na prostoru Alpa 2000. i 2012. godine bilo manje od 2 milijuna kuća za odmor (ili $26 \%$ od ukupnoga stambenog fonda). Autori upućuju i na očiglednu razliku u prostornom razmještaju vikendica u alpskom prostoru - većina ih se nalazi u zapadnom dijelu Alpa (posebice u Francuskoj i Italiji, gdje udio takvih stambenih jedinica u mnogim općinama prelazi $80 \%$ ukupnoga stambenog fonda), dok se najmanje vikendica nalazi $u$ istočnom dijelu (uključujući Sloveniju). Razlozi za to leže u prirodnim (reljef) i kulturnim (zakoni, državni propisi) obilježjima pojedinih zemalja. Autori prepoznaju Sloveniju kao zemlju gdje je broj vikendica $u$ alpskom prostoru doživio najveći porast u posljednja dva desetljeća (prema njihovim procjenama 2012. godine postojalo je otprilike 40,000 stambenih jedinica za odmor i rekreaciju). Među glavnim razlozima za naglo širenje vikendica u Alpama navode činjenicu da se radi o tradicionalno turističkom području (s rastućim brojem turista) gdje (u slučaju nekih općina) vladaju emigracijski procesi stalnoga stanovništva. Sonderegger i Bätzing nisu se dublje usredotočili na prostorni aspekt i specifične utjecaje vikendaštva u alpskom prostoru.

U posljednjih su pet desetljeća vikendice u slovenskom (jugoslavenskom do 1991.) dijelu Alpa proučavali brojni geografi, arhitekti i antropolozi. Oni su uglavnom bili usredotočeni na širu regiju istočnih Julijskih Alpa - područje koje se znatno preklapa s NPT i koje je, zbog svojih prirodnih vrijednosti, posebno privlačno i pogodno područje za provođenje slobodnoga vremena. Najveći broj studija bavio se područjem današnje općine Bohinj (Vojvoda, 1965; Kalan, 1983; Gosar, 1987; 1988; Bajuk Senčar, 2005; Koderman i Salmič, 2013); među zanimljivijim područjima za istraživanje
Second homes in the Slovenian Alps with special emphasis on the Municipality of Bovec

Vikendice u slovenskim Alpama s posebnim naglaskom na općinu Bovec 
The geographer Anton Gosar was the first to discuss the problem of second homes in the area of the contemporary municipality of Bovec. This area was then part of the former municipality of Tolmin, so there are relatively few findings regarding the settlements of what would become the municipality of Bovec. He published the results of his studies in the dissertation entitled Second Homes as an Element of Transformation of Slovene Alpine Landscapes (Gosar, 1988). In his work, he analysed the geographical distribution of second homes for the entire north-western part of Slovenia. Here, the town of Bovec (including Kaninska Vas) and the village of Trenta stood out with the highest number of such dwellings, while fewer dwellings were registered in the settlements of Soča, Log pod Mangartom, and Strmec na Predelu. The share of second homes in the housing stock of Bovec and Trenta was at that time comparable to that in the area of Bohinj (Goreljek, Polje, Ribčev Laz, Ukanc), where the share of the secondary housing stock was among the largest in Slovenia (Gosar, 1988). Gosar further noted that a decline in the number of permanent residents was evident in many settlements located in the Slovene Alpine regions. He found out that in the 1980s second homes already represented the dominant form of settlement in some Alpine areas, or that they represented a significant share within the housing stock-in the area of the municipality of Bovec this applied to the settlements Bavšica, Lepena, and Trenta.

Geographer and social anthropologist Matej Vranješ (Vranješ, 2005; 2008) also studied the phenomenon of second homes in the municipality of Bovec. In his research he mainly dealt with the question of the impact of these dwellings on the cultural landscape. After the Second World War, the Bovec Region was exposed to intense socio-economic, spatial, and demographic changes. The processes of rapid deagrarisation and relative industrialisation were particularly prominent. Industrialisation, however, did not develop to such an extent that it could retain the population which at that time emigrated from the agrarian overpopulated Alpine valleys. Vranješ also argues that the abandonment of farming (primarily sheep breeding and mountain pasturing) and mass emigration of the toga fenomena bile su općine Kranjska Gora (Gosar, 1988; Salmič i Koderman, 2013) i Bovec (Gosar, 1988; Vranješ, 2005; 2008).

Geograf Anton Gosar prvi se bavio problemom vikendaštva na području današnje općine Bovec. To je područje bilo dio nekadašnje općine Tolmin, tako da je razmjerno malo nalaza u vezi s naseljima koja će postati današnja općina Bovec. Rezultate svojih istraživanja objavio je u doktorskom radu pod nazivom Vikendice kao element transformacije slovenskih alpskih područja (Gosar, 1988). U svojem je radu analizirao geografski razmještaj vikendica u čitavom sjeverozapadnom dijelu Slovenije. Pritom su se grad Bovec (uključujući Kaninsku Vas) i selo Trenta istaknuli najvećim brojem kuća za odmor, dok je manji broj registriran u naseljima Soča, Log pod Mangartom i Strmec na Predelu. Udio vikendica u stambenom fondu Bovca i Trente u to je vrijeme bio usporediv s onim na području Bohinja (Goreljek, Polje, Ribčev Laz, Ukanc), gdje je udio fonda vikendica bio među najvećima u Sloveniji (Gosar, 1988). Gosar je uočio i da je smanjenje broja stalnih stanovnika bilo zabilježeno u mnogim naseljima slovenskoga alpskog prostora. Primijetio je da su 1980-ih vikendice već bile dominantan oblik stambenih jedinica u nekim alpskim područjima ili su imale značajan udio $\mathrm{u}$ stambenom fondu $-\mathrm{u}$ području općine Bovec to se odnosilo na naselja Bavšica, Lepena i Trenta.

Geograf i socijalni antropolog Matej Vranješ (Vranješ, 2005; 2008) također je proučavao fenomen vikendaštva u općini Bovec. U svojim istraživanjima većinom se bavio pitanjem utjecaja vikendica na kulturni pejzaž. Nakon Drugoga svjetskog rata područje Bovca doživjelo je intenzivne društveno-gospodarske, prostorne i demografske promjene. Osobito su naglašeni bili procesi brze deagrarizacije i značajne industrijalizacije. Ipak, industrijalizacija se nije razvila u tolikoj mjeri da bi uspjela zadržati stanovništvo koje je u to vrijeme emigriralo iz prenapučenih agrarnih alpskih dolina. Vranješ također tvrdi da su napuštanje poljoprivrede (prvenstveno ovčarstva i planinske ispaše) i masovna emigracija lokalnoga stanovništva 
local population are two sides of the same process, which marked the area of the municipality of Bovec in the second half of the $20^{\text {th }}$ century. Emigrants left empty, poorly maintained houses, barns, pasture cottages, and high mountain pastures, as well as uncultivated fields that soon started to become overgrown with forest vegetation. During this period, at least two new factors entered the local environment, which had a vital impact on the process of further changing the cultural landscape of this area: these were the owners of second homes on one hand and TNP on the other. According to Vranješ (Vranješ, 2005; 2008), in the 1960s and especially the 1970s, the new owners bought up vast numbers of empty homesteads and barns and transformed them into second homes. With the need for money, local residents sold the property without hesitation, often at a low price. In the first phase, barns were sold. The properties in relatively remote valleys and higher lying hamlets (such as the villages of $\mathrm{Za}^{-}$ poden, Vrsnik, and Vas na Skali), which were first depleted, were sold fastest. As Vranješ (2008) explained, owners of second homes are perceived as a kind of "necessary evil" among the locals, as they also brought some benefits to the local community-they have contributed to preserving the traditional cultural landscape in some areas by conserving and restoring their second homes (buildings and surroundings), which would otherwise be left to dilapidation.

It has to be mentioned that the establishment of the Public Institution of TNP was implemented by the TNP Act of 1981. The act brought additional regulations and adopted a mechanism for control of "preserving and developing a cultural landscape" or spatial interventions in the national park area. For several decades, the TNP Act has prohibited the construction of new houses or enlargement of the existing housing stock, as well as changing of the purpose of existing facilities to second homes, i.e. re-zoning (The Triglav National Park Act, 1981; 2010). In recent years, the demand for such facilities has remained high, but the supply of abandoned buildings is almost non-existent, therefore only renovated and rebuilt dwellings that reach relatively high prices can be found on the market (Vranješ, 2008). dvije strane istoga procesa koji je obilježio područje općine Bovec u drugoj polovini 20. stoljeća. Iseljenici su ostavili prazne, loše održavane kuće, staje, kolibe na pašnjacima i pašnjake na velikim nadmorskim visinama te neobrađena polja koja su uskoro obrasla šumskom vegetacijom. Tijekom toga razdoblja u lokalnom su se okruženju pojavila najmanje dva nova čimbenika koja su značajno utjecala na proces daljnje promjene kulturnoga pejzaža tog područja: pojava vikendaštva s jedne strane i proglašenje NPT s druge. Prema Vranješu (Vranješ, 2005; 2008), 1960-ih te posebno 1970-ih novi su vlasnici kupili golem broj napuštenih seoskih gospodarstava i staja te ih preobrazili u vikendice. Zbog potrebe za novcem lokalno je stanovništvo bez oklijevanja prodavalo nekretnine, često po niskoj cijeni. U prvoj su fazi prodavane staje. Najbrže su se prodavale nekretnine u razmjerno zabačenim dolinama i zaseocima na visokim nadmorskim visinama (kao što su sela Zapoden, Vrsnik i Vas na Skali) koja su prva napuštena. Vranješ (2008) objašnjava da je vlasnike vikendica lokalno stanovništvo doživljavalo kao „nužno zlo” jer su lokalnoj zajednici donijeli i određene prednosti - pridonijeli su očuvanju tradicionalnoga kulturnog pejzaža u nekim područjima konzervacijom i obnovom svojih vikendica (i objekta i okućnice) koje bi inače propale.

Treba spomenuti da je Javna ustanova NPT osnovana 1981. godine Zakonom o NPT. Zakon je uveo dodatne propise i usvojio mehanizam za kontrolu „očuvanja i razvoja kulturnog pejzaža” ili prostornih intervencija u području nacionalnoga parka. Nekoliko je desetljeća Zakon o NPT branio izgradnju novih kuća i proširenje postojećega stambenog fonda, kao i promjenu svrhe postojećih objekata u vikendice, odnosno prenamjenu (Zakon o Nacionalnom parku Triglav, 1981; 2010). Posljednjih je godina potražnja za takvim objektima ostala visoka, no ponuda napuštenih objekata gotovo ne postoji, stoga se na tržištu mogu pronaći samo renovirane i ponovno izgrađene kuće za odmor koje postižu relativno visoke cijene (Vranješ, 2008).
Second homes in the Slovenian Alps with special emphasis on the Municipality of Bovec

Vikendice u slovenskim

Alpama s posebnim naglaskom na općinu Bovec 
HRVATSKI

GEOGRAFSKI

GLASNIK

81/1, 61-81 (2019.)

\section{Research methodology}

The presented research was based on the data obtained from SORS and SMARS. SORS's data illustrate the numerical scope of the observed phenomenon by five censuses carried out between 1971 and 2011. The data obtained from the Real Estate Registry of SMARS show the spatial distribution and the approximate age of second homes in the selected settlements of the municipality of Bovec.

The Real Estate Registry, which was established after conducting the real estate census in 2006 and 2007 , has repeatedly proved to be a useful source of data in various geographical surveys (among others: Komac et al., 2012; Koderman and Salmič, 2013; Salmič and Koderman, 2013; Koderman, 2014; Koderman, 2017). It includes data from the Land Register and the Cadaster of Buildings. For the purposes of this study, the data of the Real Estate Registry were analysed according to two criteria: the first criterion was the purpose of use, i.e. whether the building (or part of a building in the case of multi-apartment buildings) was being used for secondary/holiday purposes. Among the units that met this criterion, we further excluded those dwellings that were not used exclusively for private purposes. In this way we identified 610 units that were used by owners for holiday purposes in the municipality of Bovec in September 2015 (SMARS, 2015). They were the basis for analysing the second home housing stock in the relevant area that included elaboration of the detail scale maps with ArcGIS software.

This number of dwellings (610 units in 2015) should be taken into critical consideration, as there may have been instances where the owners did not identify the actual use of the dwellings or misrepresented it. The number can be compared with SORS's 2011 Register-Based Census of Buildings and Dwellings, where 632 such dwellings were registered in the area in question (SORS, 2011a). These data originate from a different year (2011) and are therefore not completely comparable with the number from 2015. Despite these numerical differences, we estimate that the data of the Real Estate Registry show a high degree of representativeness and to a large extent reflect the actual situation in regard to second homes in the municipality of Bovec, espe-

\section{Metodologija istraživanja}

Predstavljeno istraživanje temeljilo se na podacima dobivenima iz SORS-a i SMARS-a. Podaci SORS-a upućuju na numerički opseg promatranoga fenomena prema pet popisa stanovništva koji su provedeni između 1971. i 2011. godine. Podaci dobiveni iz Katastra nekretnina SMARS-a pokazuju prostorni razmještaj i procijenjeno vrijeme izgradnje vikendica u odabranim naseljima općine Bovec.

Katastar nekretnina, koji je utemeljen nakon provođenja popisa nekretnina 2006. i 2007., iznova se pokazao korisnim izvorom u brojnim geografskim istraživanjima (među ostalima: Komac i dr., 2012; Koderman i Salmič, 2013; Salmič i Koderman, 2013; Koderman, 2014; Koderman, 2017), uključuje podatke iz zemljišnih knjiga i Katastra nekretnina. Za potrebe ovoga istraživanja podaci iz Katastra nekretnina analizirani su prema dvama kriterijima: prvi je kriterij bio namjena, odnosno upotrebljava li se objekt (ili njegov dio u slučaju višestambenih zgrada) u sekundarnu svrhu / za odmor. Iz jedinica koje su zadovoljile taj kriterij dodatno su isključene stambene jedinice za odmor koje se nisu upotrebljavale isključivo u privatne svrhe. $\mathrm{Na}$ taj je način identificirano 610 jedinica koje su vlasnici upotrebljavali za odmor u općini Bovec u rujnu 2015. (SMARS, 2015). One su bila osnova za analizu stambenoga fonda vikendica u relevantnom području, koja je uključivala izradu detaljnih karata pomoću softvera ArcGIS.

Taj broj kuća za odmor (610 jedinica u 2015.) treba uzeti s oprezom jer je moguće da vlasnici nisu identificirali stvarnu uporabu kuće ili su je namjerno pogrešno naveli. Broj se može usporediti s Popisom objekata i kuća za odmor iz 2011. godine koji je proveo SORS i u kojem su registrirane 632 takve kuće u navedenom području (SORS, 2011a). Međutim, budući da se ti podaci odnose na 2011. godinu, nisu u potpunosti usporedivi s brojem iz 2015. godine. Ipak, unatoč razlikama u broju može se reći da su podaci iz Katastra nekretnina u visokom stupnju reprezentativni i da u velikoj mjeri odražavaju stvarnu situaciju u pogledu vikendica u općini 
cially in the areas with the highest concentration of such dwellings (settlements Bovec, Trenta, and Log pod Mangartom). It has to be mentioned that the obtained data represent official estimates gathered by SORS's census and SMARS. It can be assumed that the number of second homes in the debated area is even higher due to the speculative reasons of some individual second home owners.

\section{Analysis of second homes in the municipality of Bovec: results and discussion}

The number of second homes in the municipality of Bovec grew by 734.9 index points between 1971 and 2015. As shown in Tab. 1, the largest increase was recorded in the town of Bovec (5071.4 index points) while relatively high growth can be seen also in settlements of Log pod Mangar-
Bovec, posebice u područjima s najvećom koncentracijom takvih kuća (naselja Bovec, Trenta i Log pod Mangartom). Treba spomenuti da su dobiveni podaci službene procjene prikupljene u SORS-ovu popisu i SMARS-u, a može se pretpostaviti da je broj vikendica na tom području čak i veći zbog spekulativnih razloga nekih vlasnika.

\section{Analiza vikendica u općini Bovec: rezultati i rasprava}

Broj vikendica u općini Bovec narastao je za 734,9 indeksnih bodova između 1971. i 2015. godine. Kao što je prikazano u tab. 1, najveći porast zabilježen je u gradu Bovec (5071,4 indeksnih bodova), dok je relativno visok porast vidljiv u naseljima Log pod Mangartom (477,8
M. Koderman M. Pavlič

Second homes in the Slovenian Alps with special emphasis on the Municipality of Bovec

Vikendice u slovenskim Alpama s posebnim naglaskom na općinu Bovec

Tab. 1 Number of second homes in the municipality of Bovec in different periods

Tab. 1. Broj vikendica u općini Bovec u različitim razdobljima

\begin{tabular}{|c|c|c|c|c|c|c|c|c|c|c|c|c|c|}
\hline 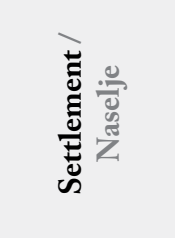 & 독 & 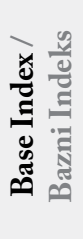 & $\bar{\sigma}$ & 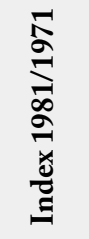 & Бे & 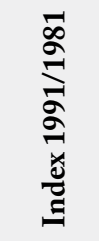 & ฮิ่ & 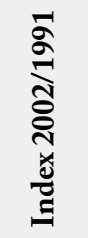 & $\overline{\bar{\delta}}$ & 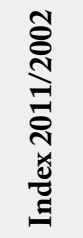 & ำ & 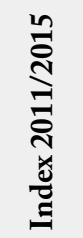 & 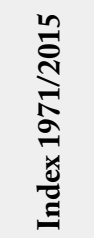 \\
\hline Bovec & 7 & 100.0 & 34 & 485.7 & 481 & 1414.7 & 82 & 17.1 & 378 & 461.0 & 355 & 93.9 & 5071.4 \\
\hline Čezsoča & 7 & 100.0 & 19 & 271.4 & 32 & 168.4 & 43 & 134.4 & 31 & 72.1 & 32 & 103.2 & 457.1 \\
\hline $\begin{array}{c}\text { Log pod } \\
\text { Mangartom }\end{array}$ & 9 & 100.0 & 24 & 266.7 & 38 & 158.3 & 45 & 118.4 & 43 & 95.6 & 43 & 100.0 & 477.8 \\
\hline Soča & 15 & 100.0 & 45 & 300.0 & 54 & 120.0 & 56 & 103.7 & 37 & 66.1 & 42 & 113.5 & 280.0 \\
\hline Srpenica & 9 & 100.0 & 4 & 44.4 & 14 & 350.0 & 22 & 157.1 & 13 & 59.1 & 12 & 92.3 & 133.3 \\
\hline Trenta & 23 & 100.0 & 56 & 243.5 & 76 & 135.7 & 81 & 106.6 & 67 & 82.7 & 66 & 98.5 & 287.0 \\
\hline Žaga & 0 & 100.0 & 5 & / & 10 & 200.0 & 18 & 180.0 & 15 & 83.3 & 13 & 86.7 & / \\
\hline $\begin{array}{l}\text { Other*/ } \\
\text { Ostalo* }\end{array}$ & 13 & 100.0 & 52 & 400.0 & 66 & 126.9 & 90 & 136.4 & 48 & 53.3 & 47 & 97.9 & 361.5 \\
\hline $\begin{array}{l}\text { Municipali- } \\
\text { ty of Bovec } \\
\text { Općina Bovec }\end{array}$ & 83 & 100.0 & 239 & 288.0 & 771 & 322.6 & 437 & 56.7 & 632 & 144.6 & 610 & 96.5 & 734.9 \\
\hline
\end{tabular}

Source: Census of Population and Dwellings, 1971; Census of Population, Households and Dwellings in SR Slovenia, 31. 3. 1981; Census of Dwellings, 1991; Census of Dwellings, 2002; 2011a; SMARS, 2015

Izvor: Popis stanovništva i stanova, 1971.; Popis stanovništva, Kućanstava i stanova u SR Sloveniii, 31 3. 1981.; Popis stanova, 1991.; Popis stanova, 2002. 2011 ; SMARS, 2015.

* The category "Other" includes the settlements Bavšica, Kal-Koritnica, Lepena, Log Čezsoški, Plužna, and Strmec na Predelu.

* Kategorija "Ostalo" uključuje naselja Bavšica, Kal-Koritnica, Lepena, Log Čež̌oski, Plužna i Strmec na Predelu. 
tom (477.8 index points) and Čezsoča (457.1 index points). Certain fluctuations in the number of second homes can be observed in some municipal settlements in different periods. The largest number of such dwellings was recorded in 1991, when a total of 771 units were registered; this number later decreased to 437 second homes in 2002, while in 2011 the number grew to 632. As mentioned, the number in SMARS's Real Estate Registry in 2015 was 610 second homes.

There are several reasons for periodical fluctuations in the census years. To a large extent, they can be explained by the depopulation trends which have appeared in the broader region of the Upper Soča Valley after the Second World War and have consequently resulted in the real estate sales that later resulted in transformation of the properties into second homes. Moderate growth or decrease in the number of second homes in some settlements in the recent years can be attributed to the legislation implemented with the TNP Act, which introduced limitations on the construction and expansion of settlements in the national park area (only some municipal settlements were affected by this regulation).

Furthermore, the 2002 census showed a sharp decrease in the number of holiday homes in the town of Bovec (from 481 units in 1991 to 82 units in 2002) and was also crucial in terms of reducing the total number of these facilities at the municipal level in the 2002 census. According to the official representative of SORS responsible for data in the field of second homes, the reasons for such a drastic reduction lie in the fact that a large number of dwellings in Kaninska Vas in the town of Bovec (initially categorised as second homes) were later declared as permanent residences by the owners (Miklič, 2016). In addition, the census methodology was changed in 2011, as SORS conducted a register-based census. Its main sources were the Real Estate Registry, maintained by SMARS, as well as the Central Population Registry and the Registry of Households, which are both maintained by the Ministry of the Interior, and the Building Cadastre and the Land Registry that is managed by the $\mathrm{Su}-$ preme Court of the Republic of Slovenia.

According to statistical data (Tab. 1), second homes in the municipality recorded the highest indeksnih bodova) i Čezsoča (457,1 indeksnih bodova). Određene promjene u broju vikendica mogu se primijetiti u nekim općinskim naseljima u različitim razdobljima. Najveći broj takvih kuća zabilježen je 1991., kada je registrirana 771 stambena jedinica namijenjena odmoru i rekreaciji; taj se broj kasnije smanjio na 437 vikendica u 2002 ., dok je u 2012. narastao na 632 vikendice. Kao što je spomenuto, u Katastru nekretnina SMARS-a u 2015. registrirano je 610 vikendica.

Postoji nekoliko razloga za periodičke promjene broja vikendica u godinama kad je rađen popis. Oni se u značajnoj mjeri mogu objasniti trendovima depopulacije koji su se pojavili u široj regiji doline gornje Soče nakon Drugoga svjetskog rata te su uzrokovali prodaju nekretnina koja je kasnije dovela do transformacije stambenoga fonda u vikendice. Umjereni porast ili pad broja vikendica u nekim naseljima posljednjih godina može se pripisati zakonima uvedenima u sklopu Zakona o NPT koji je uveo ograničenja za izgradnju i širenje naselja u području nacionalnoga parka (taj se zakon odnosi samo na neka općinska naselja).

Nadalje, popis stanovništva iz 2002. pokazao je oštar pad broja vikendica u gradu Bovcu (s 481 jedinice 1991. na 82 jedinice 2002. godine) te je također bio ključan u smislu smanjenja ukupnoga broja tih objekata na razini općine u popisu iz 2002. godine. Službeni predstavnik SORS-a za podatke vezane uz područje vikendica kaže da razlozi za to drastično smanjenje leže u činjenici da su velik broj kuća za odmor u Kaninskoj Vasi u gradu Bovcu (isprva kategoriziranih kao vikendice) vlasnici kasnije registrirali kao svoje trajno prebivalište ( $\mathrm{Mi}$ klič, 2016). Usto je metodologija popisivanja promijenjena 2011. godine jer je SORS proveo popisivanje na bazi registra. Njihovi glavni izvori bili su Katastar nekretnina koji održava SMARS, kao i Središnji registar stanovništva i Registar domaćinstava koje održava Ministarstvo unutarnjih poslova te Katastar objekata i Zemljišne knjige kojima upravlja Vrhovni sud Republike Slovenije.

Prema statističkim podacima (tab. 1) vikendice u općini zabilježile su najveće povećanje između 


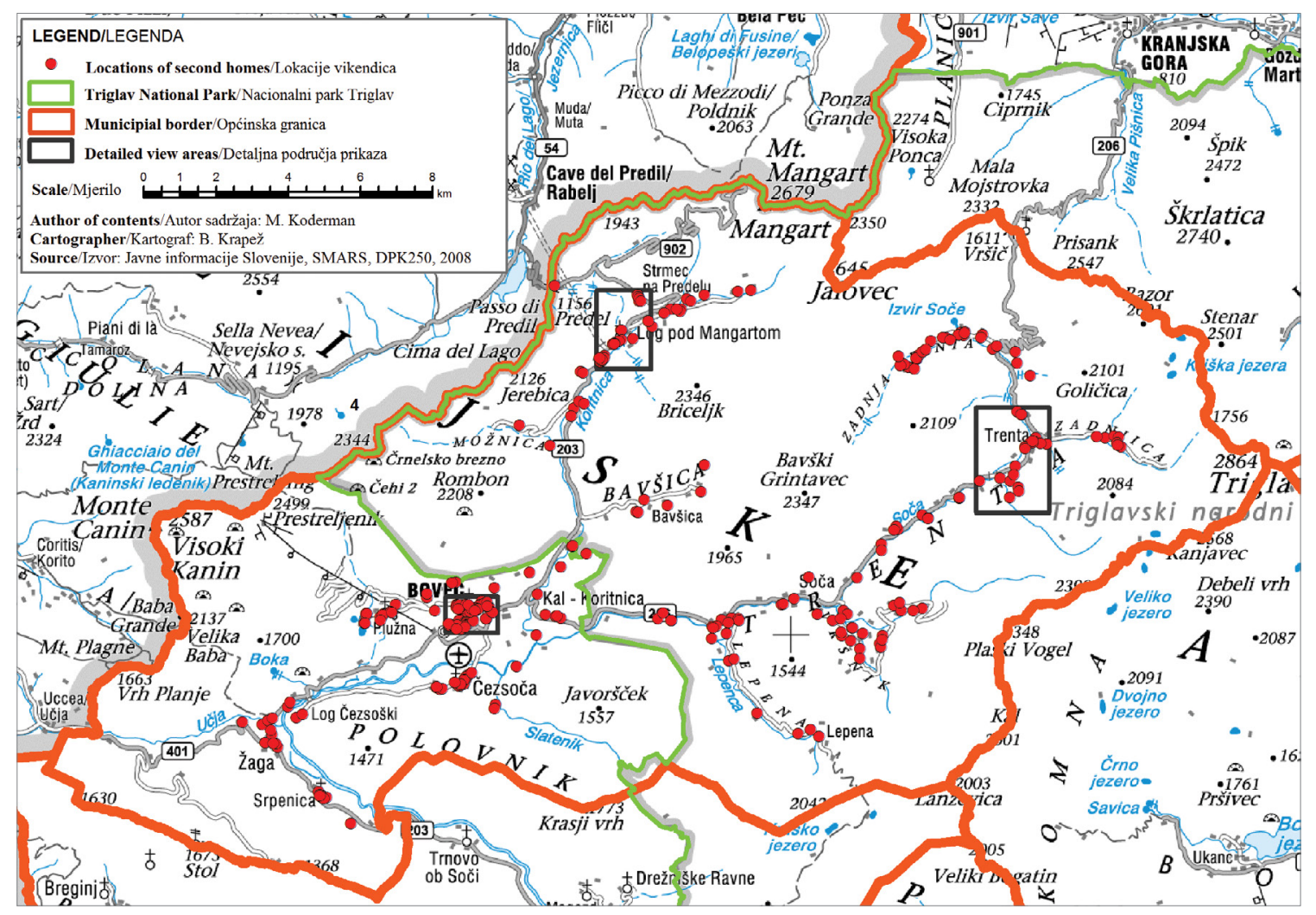

Second homes in the Slovenian Alps with special emphasis on the Municipality of Bovec

Vikendice u slovenskim Alpama s posebnim naglaskom na općinu Bovec

Fig. 2 Spatial distribution of second homes in the municipality of Bovec in 2015

SI. 2. Prostorni razmještaj vikendica u općini Bovec 2015. godine

growth between 1981 and 1991, when an increase of 322.5 index points was registered at the municipal level. During this period, apartment complexes with holiday accommodation in the area of $\mathrm{Ka}^{-}$ ninska Vas were built. The number of apartments built for secondary/holiday use increased by more than 400 units (1414.7 index points) in the town of Bovec alone.

Second homes can be found in all thirteen settlements of the municipality, but their numerical representation varies from one settlement to another (Tab. 1). Based on our analysis of the Real Estate Registry data, we identified general locations of the municipal second home housing stock in Fig. 2. Three settlements in municipality that stand out in the number of second homes were analysed on detail scale maps: Bovec, Trenta, and Log pod Mangartom with its surroundings (Fig. 3, Fig. 4, Fig. 5).
1981. i 1991. kada je porast od 322,5 indeksnih bodova registriran na razini općine. Tijekom toga razdoblja izgrađene su višestambene apartmanske zgrade za odmor i rekreaciju na području Kaninske Vasi. Broj stanova izgrađenih u svrhu sekundarnoga korištenja / vikendaštva porasla je za više od 400 jedinica (1414,7 indeksnih bodova) samo u gradu Bovcu.

Vikendice su registrirane u svih trinaest naselja u općini, no njihova brojčana zastupljenost razlikuje se od jednoga do drugoga naselja (tab. 1). $\mathrm{Na}$ temelju analize podataka iz Katastra nekretnina identificirane su približne lokacije vikendica u općini (sl. 2). Tri naselja u općini koja se ističu brojem vikendica (Bovec, Trenta i Log pod Mangartom s okolicom) analizirana su na detaljnim kartama (sl. 3, sl. 4, sl. 5). 
HRVATSKI

GEOGRAFSKI

GLASNIK

81/1, 61-81 (2019.)

\section{The town of Bovec}

The largest number of second homes is located in the central and most developed urban area of the municipality - the town of Bovec (Fig. 3), where in July, 2015 a total of 355 units were recorded (SMARS, 2015). The number of these dwellings in Bovec has increased by more than 50 times since 1971, which means that the construction of second homes has contributed significantly to the changes in this once-traditional Alpine village settlement.

Fig. 3 shows that independent single-family houses intended for holiday use are relatively evenly distributed throughout the town. A considerable proportion of these houses were built before the Second World War, so the function of these dwellings was later converted from residential to second homes. There are relatively few newer facilities—only $19 \mathrm{sec}-$ ond homes in the town of Bovec were built after 1990. A number of multi-apartment buildings or complexes are clearly evident on the outskirts of the town, dominating the settlement's north-western (Kaninska Vas) and south-western parts (Brdo). In the last four decades, similar multi-apartment complexes significantly transformed the traditional structure of some Alpine settlements in Slovenia, e.g. in Kranjska Gora (Salmič and Koderman, 2013) and Bohinjska Bistrica (Koderman and Salmič, 2013). Such multi-apartment complexes can be considered as a relatively recent morphological form of second homes in major tourist resorts, although some of them (as in the case of Bovec) were built already in the 1980s.

The changes in the urban structure of the settlements happened not only due to the extensive dimensions of the multi-apartment buildings, but also because of their general architectural appearance, since most of these dwellings stand out from the surrounding area. Although the appearance and size of such buildings should be in accordance with municipal laws and decrees that cover the field of urban planning and construction (in the town of Bovec for example Ordinance on the Municipal Spatial Plan 2008) (Ordinance on the municipal spatial plan of Bovec, 2008), exceptions to these regulations are often allowed by the municipal authorities in order to stimulate investments and development. Because of their disrespect of traditional architectural elements,

\section{Grad Bovec}

Najveći broj vikendica nalazi se u središnjem i najrazvijenijem urbanom području općine - gradu Bovcu (sl. 3), gdje je u srpnju 2015. godine zabilježeno ukupno 355 jedinica (SMARS, 2015). Broj takvih kuća u Bovcu narastao je više od 50 puta od 1971., što znači da je izgradnja vikendica značajno pridonijela promjenama u tom nekada tradicionalnom alpskom seoskom naselju.

Slika 3 prikazuje da su obiteljske kuće namijenjene odmoru razmjerno ravnomjerno raspoređene na području grada. Znatan udio tih kuća izgrađen je prije Drugoga svjetskog rata, stoga su te kuće kasnije prenamijenjene iz stambenih jedinica za stalno stanovanje u vikendice. Postoji razmjerno malen broj novijih kuća - samo 19 vikendica u gradu Bovcu izgrađeno je nakon 1990. godine. Određen broj višestambenih zgrada namijenjenih sekundarnom stanovanju jasno je vidljiv na rubovima grada te dominira sjeverozapadnim (Kaninska Vas) i jugozapadnim dijelovima naselja (Brdo). U posljednja četiri desetljeća slične su višestambene apartmanske zgrade značajno transformirale tradicionalnu strukturu nekih alpskih naselja u Sloveniji, primjerice u Kranjskoj Gori (Salmič i Koderman, 2013) i Bohinjskoj Bistrici (Koderman i Salmič, 2013). Te se višestambene apartmanske zgrade mogu smatrati relativno novim morfološkim oblikom vikendica u značajnijim turističkim mjestima iako su pojedine apartmanske zgrade (kao u slučaju Bovca) izgrađene još 1980-ih.

Promjene u urbanoj strukturi naselja nisu se odvile samo zbog velikih dimenzija višestambenih apartmanskih zgrada nego i zbog njihova općenitoga arhitektonskog izgleda s obzirom na to da većina te gradnje izgledom odskače od fizionomije okolnoga područja. Iako bi izgled i veličina tih zgrada trebali biti u skladu s općinskim zakonima i odredbama koji se odnose na urbano planiranje i izgradnju (u gradu Bovcu, primjerice, Pravilnik o općinskom prostornom planu iz 2008.) (Pravilnik o općinskom prostornom planu Bovca, 2008), lokalne vlasti često dopuštaju iznimke u propisima da bi se potaknulo ulaganje i razvoj. S obzirom na nepoštivanje tradicionalnih arhitektonskih ele- 


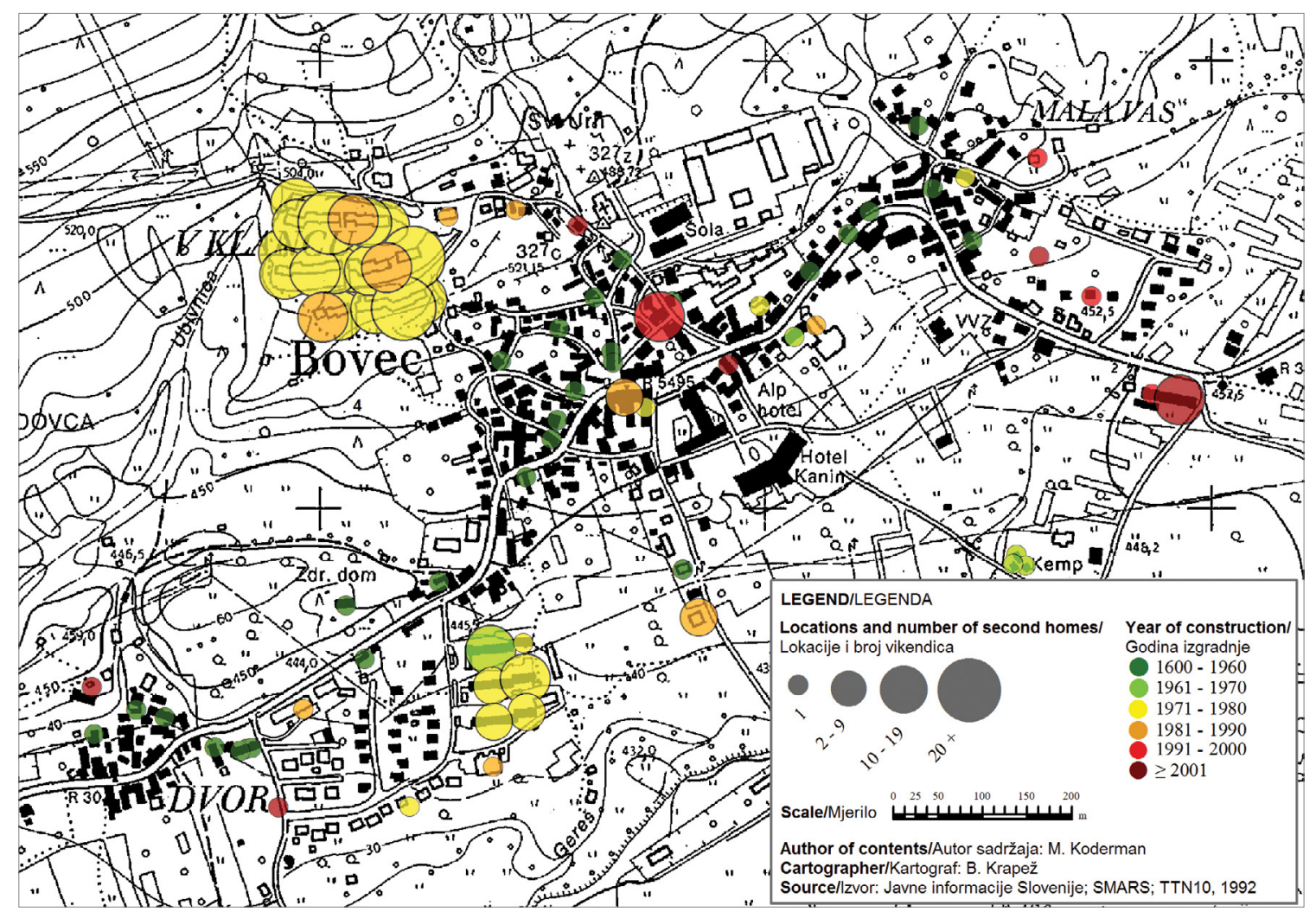

Second homes in the Slovenian Alps with special emphasis on the Municipality of Bovec

Vikendice u slovenskim

Alpama s posebnim naglaskom na općinu Bovec

Fig. 3 Spatial distribution of second homes in the town of Bovec in 2015 SI. 3. Prostorni razmještaj vikendica u gradu Bovcu 2015. godine

several complexes were proclaimed "a thorn in the eye" by the local community, whose opposition to similar projects did not influence investor plans (Koderman, 2014). In this regard, the debated discussion and opposition resembles the reluctance of some local communities, studied by Kaltenborn et al. (2009) and Farstad and Rye (2013). The latter noted that permanent residents and owners of second homes in Norway are in some cases fairly reluctant to accept construction of new second homes, as well as the expansion of services in areas where they reside. Both, permanent residents and owners of second homes, consider such spatial interventions as necessary, but are unwilling to have them in their immediate vicinity. The authors point out the "not in my backyard" mentality often. Regarding the example of second homes in Norway, Kaltenborn et al. (2009) write about the concerns of second home owners that they have as a result of the tendency to protect the environment. They highlight the problem of new construction and the expansion of services in Norwegian mountain areas in particular, menata lokalna je zajednica nekoliko takvih višestambenih apartmanskih zgrada nazvala „trnom u oku", no njihov otpor sličnim projektima ipak nije utjecao na planove ulagača (Koderman, 2014). U tom pogledu, žustra rasprava i otpor podsjećaju na nevoljkost nekih lokalnih zajednica, koje su proučavali Kaltenborn i dr. (2009) i Farstad i Rye (2013). Farstad i Rye (2013) opazili su da su stalni stanovnici i vlasnici vikendica u Norveškoj u nekim slučajevima donekle neskloni prihvatiti izgradnju novih vikendica kao i širenje usluga u područjima gdje žive. I stalni stanovnici i vlasnici vikendica smatraju takve prostorne intervencije potrebnima, no ne žele ih u neposrednoj blizini. Autori često upozoravaju na mentalitet „ne u mojem dvorištu". Takav je slučaj s vlasnicima vikendica u Norveškoj. Nadalje, Kaltenborn i dr. (2009) pišu o zabrinutosti vlasnika vikendica koja proizlazi iz sklonosti k zaštiti okoliša. Naglašavaju problem nove izgradnje i širenja usluga, posebice u norveškim planinskim područjima, gdje se 
where owners with high environmental awareness oppose any further interventions and are satisfied with staying in their second homes without the access to the public services (water supply, electricity, waste water treatment, etc.).

Multi-apartment complexes in Kaninska Vas and (to a lesser extent) multi-apartment buildings and terraced houses in the south-western part of the town called Brdo have significantly contributed to the expansion of the ground plan of the settlement since their construction in the 1980s. Buildings in the area of Kaninska Vas (at the addresses of Kaninska Vas 1-23) were built between 1980 and 1986, and some of them consist of over 20 second home apartments. According to the Real Estate Register, over three quarters (or 270 out of 355) of all holiday units were concentrated in these multi-apartment buildings in 2015 (SMARS, 2015); therefore, we could classify the area of Kaninska Vas as a "second home quarter" in the town of Bovec.

Most other settlements in the municipality of Bovec have a generally dispersed ground plan. The hamlets, comprised of individual dispersed homesteads, can be found in villages Trenta, Soča, Vrsnik, Lepena and Bavšica, and Strmec na Predelu. Congested nucleus type of the settlements, where the buildings are usually located on both sides of the main road, are found in hamlets $\mathrm{Na} \operatorname{Logu}$ (part of the village of Trenta) and in the villages of Soča, Strmec na Predelu, and Log pod Mangartom (with hamlets Gorenji and Spodnji Log) (Analysis of settlement status, 2012).

\section{The village of Trenta}

Some settlements in the municipality (i.e. the village of $\check{Z}_{\text {aga }}$ in conjunction with the village of Srpenica, the villages of Trenta and Soča, as well as Log pod Mangartom) were once considered as local centres with their own gravitational hinterland. In recent years, due to the insufficient number of permanently settled inhabitants and rationalisation of businesses in these settlements, branch elementary schools and kindergartens have been abolished (Ordinance on the municipal spatial plan of Bovec, 2008), while local shops and village taverns have closed down or begun operating on a seasonal schedule. Some settlements vlasnici, koji su veoma ekološki osviješteni, opiru svakoj novoj intervenciji i zadovoljni su korištenjem svojih vikendica bez pristupa komunalijama (vodovodu, električnoj mreži, sustavu zbrinjavanja otpadnih voda itd.).

Apartmanske zgrade u Kaninskoj Vasi i (u manjoj mjeri) višestambene apartmanske zgrade te terasaste kuće namijenjene odmoru i rekreaciji u jugozapadnom dijelu grada zvanom Brdo značajno su pridonijele širenju tlocrta naselja otkad su izgrađene 1980-ih. Zgrade u području Kaninske Vasi (na adresama Kaninska Vas 1-23) izgrađene su između 1980. i 1986., a neke od njih sastoje se od više od 20 stanova koji služe kao vikendice. Prema Katastru nekretnina, više od tri četvrtine (ili 270 od 355) svih jedinica za odmor nalazilo se u tim stambenim zgradama 2015. godine (SMARS, 2015), stoga područje Kaninske Vasi možemo okarakterizirati kao „četvrt vikendica" u gradu Bovcu.

Većina drugih naselja u općini Bovec u pravilu ima disperzni tlocrt. Zaseoci koji se sastoje od pojedinačnih raštrkanih seoskih gospodarstva nalaze se u selima Trenta, Soča, Vrsnik, Lepena i Bavšica te Strmec na Predelu. Naselja zbijenoga tipa s jezgrom, gdje se građevine obično nalaze s obiju strana glavne ceste, prisutna su u zaseoku Na Logu (dio sela Trenta) i selima Soča, Strmec na Predelu i Log pod Mangartom (sa zaseocima Gorenji i Spodnji Log) (Analiza statusa naselja, 2012).

\section{Selo Trenta}

Neka naselja u općini (primjerice, selo Žaga povezano sa selom Srpenica, sela Trenta i Soča, kao i Log pod Mangartom) nekad su smatrana lokalnim središtima zajedno sa zaleđem koje im gravitira. Posljednjih su godina, uslijed nedovoljna broja stalnoga stanovništva i racionalizacije poslovanja u tim naseljima, područne osnovne škole i vrtići ukinuti (Pravilnik o općinskom prostornom planu, 2008), dok su lokalne trgovine i seoske gostionice zatvorene ili rade sezonski. U nekim se naseljima tako tijekom desetljeća pojavio velik udio kuća za odmor u stambenom fondu, kao 
Tab. 2 Share of second homes in the housing stock of the municipality of Bovec in 2011

Tab. 2. Udio vikendica u stambenom fondu općine Bovec 2011 . godine

\begin{tabular}{|c|c|c|c|}
\hline $\begin{array}{l}\text { Settlement / } \\
\text { Naselje }\end{array}$ & $\begin{array}{c}\text { Number of dwellings } \\
\text { / Broj kuća }\end{array}$ & $\begin{array}{c}\text { Number of second } \\
\text { homes / } \\
\text { Broj vikendica }\end{array}$ & $\begin{array}{c}\text { Share of second } \\
\text { homes in the } \\
\text { housing stock (in } \\
\text { \%) / } \\
\text { Udio vilkendica u } \\
\text { stambenom fondu } \\
(\%)\end{array}$ \\
\hline Trenta & 166 & 67 & 40.4 \\
\hline Strmec na Predelu & 28 & 9 & 32.1 \\
\hline Log pod Mangartom & 145 & 43 & 29.7 \\
\hline Bovec & 1.400 & 378 & 27.0 \\
\hline Bavšica & 27 & 7 & 25.9 \\
\hline Soča & 165 & 37 & 22.4 \\
\hline Plužna & 60 & 13 & 21.7 \\
\hline Lepena & 51 & 9 & 17.6 \\
\hline Čezsoča & 221 & 31 & 14.0 \\
\hline Srpenica & 97 & 13 & 13.4 \\
\hline Kal-Koritnica & 83 & 8 & 9.6 \\
\hline ŽZaga & 205 & 15 & 7.3 \\
\hline Log Čezsoški & 44 & 2 & 4.6 \\
\hline Municipality of Bovec / Općina Bovec & 2.692 & 632 & 23.5 \\
\hline Slovenia/Slovenija & 844.656 & 20.740 & 2.5 \\
\hline
\end{tabular}

Source / lzvor: SORS, 2011 b; $2011 \mathrm{c}$

have therefore gained a large share of holiday homes in their housing stock over the decades, as presented in Tab. 2. In this respect, settlement Trenta stands out, where over $40 \%$ of all buildings in the settlement were (officially) used for temporarily residence in 2011, while a high share of second homes (at least 25\%) was recorded in settlements Strmec na Predelu, Log pod Mangartom, Bovec, and Bavšica.

Fig. 4 shows the locations of the houses, barns and stables in the hamlet $\mathrm{Na} \operatorname{Logu}$ (part of the village of Trenta), where a traditional village nucleus can still be recognised. Such spatial distribution of houses is mainly a consequence of people's adaptation to the Alpine environment: fertile flat terrain used for agriculture was rare and therefore considered precious, while houses and other farm buildings were usually densely located near the main road or at crossroads. In this respect, other parts of Trenta are different, as
Second homes in the Slovenian Alps with special emphasis on the Municipality of Bovec

Vikendice u slovenskim Alpama s posebnim naglaskom na općinu Bovec što je prikazano u tab. 2. U tom se pogledu ističe naselje Trenta, gdje se 2011. godine više od $40 \%$ građevina u naselju (službeno) upotrebljavalo kao privremeno boravište, dok je velik udio vikendica (najmanje $25 \%$ ) zabilježen u naseljima Strmec na Predelu, Log pod Mangartom, Bovec i Bavšica.

Slika 4 prikazuje položaje kuća, hambara i štala u zaseoku Na Logu (dio sela Trenta), gdje se može prepoznati tradicionalnu jezgru naselja. Takav prostorni razmještaj većinom je posljedica ljudske prilagodbe na alpsko okruženje: plodan ravni teren koji se upotrebljava za poljoprivredu bio je rijetka pojava te se stoga smatrao dragocjenim, dok su kuće i druge gospodarske zgrade obično bile gusto raspoređene blizu glavne ceste ili na raskrižjima. U tom se pogledu drugi dijelovi Trente razlikuju jer su građevine i kuće raspršene te se u nekim slučajevima nalaze 
HRVATSKI GEOGRAFSKI GLASNIK

81/1, 61-81 (2019.)

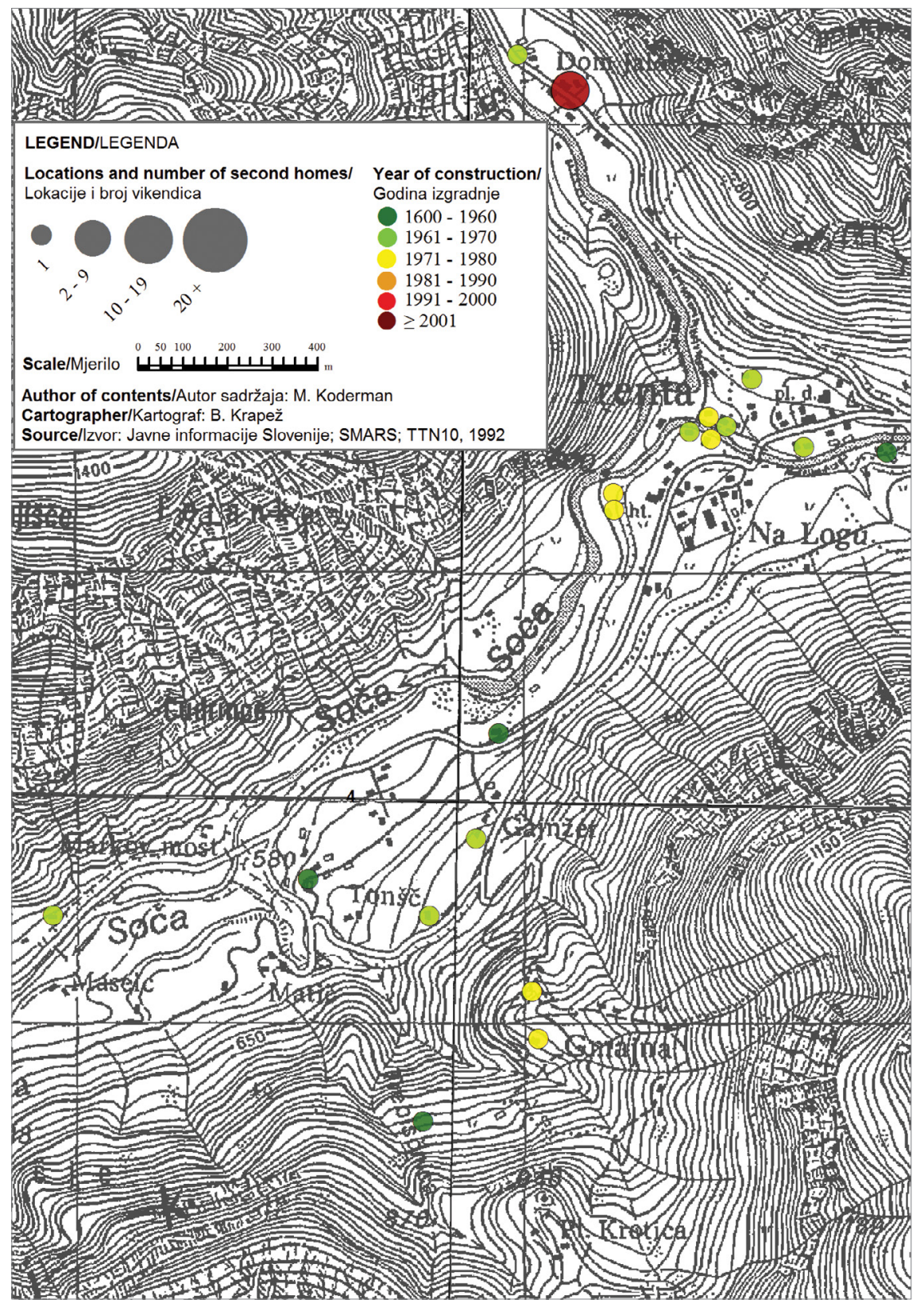

Fig. 4 Spatial distribution of second homes in the settlement of Trenta in 2015 SI. 4. Prostorni razmještaj vikendica u naselju Trenta 2015. godine buildings and houses are dispersed and in some cases stand as far as 100 meters away from one another. In this settlement, the second homes mostly are renovated family houses with one residential unit-it is interesting to note that 35 out of 66 holiday houses in Trenta were built before the Second World War. According to the Real Estate Register, only one two-apartment building was used for holiday purposes in the settlement of Trenta in 2015 (built in 2002 and shown by a brown dot in Fig. 4) (SMARS, 2015). čak i na 100 metara udaljenosti jedna od druge. $\mathrm{U}$ ovom su naselju vikendice uglavnom obnovljene obiteljske kuće s jednom stambenom jedinicom - zanimljivo je zapažanje da je 35 od 66 vikendica u Trenti izgrađeno prije Drugoga svjetskog rata. Prema Katastru nekretnina samo se jedna zgrada s dva stana upotrebljavala za odmor u naselju Trenta 2015. godine (izgrađena 2002. i prikazana smeđom točkom na slici 4) (SMARS, 2015). 


\section{The village of Log pod Mangartom}

The share of second homes in the housing stock is also high in the villages of Strmec na Predelu (32.1\%) and Log pod Mangartom (29.7\%). Fig. 5 shows both the settlements, which developed along the important historic trade route from Bovec via Predel and further to Carinthia. The transport and trade therefore characterised the development of both villages, where some of the older buildings once operated as inns for horse and cart drivers (Analysis of settlement status, 2012).

\section{Selo Log pod Mangartom}

Udio vikendica u stambenom fondu također je velik u selima Strmec na Predelu (32,1 \%) i Log pod Mangartom (29,7\%). Slika 5 prikazuje oba naselja koja su se razvila uzduž važne povijesne trgovačke rute iz Bovca preko Predela dalje do Koruške. Transport i trgovina tako su obilježili razvoj obaju sela, pri čemu su neke od starijih građevina funkcionirale kao prenoćišta za kočijaše (Analiza statusa naselja, 2012).
M. Koderman M. Pavlič

Second homes in the Slovenian Alps with special emphasis on the Municipality of Bovec

Vikendice u slovenskim Alpama s posebnim naglaskom na općinu Bovec
Fig. 5 Spatial distribution of second homes in the settlements of Log pod Mangartom and Strmec na Predelu in 2015

SI. 5. Prostorni razmještaj vikendica u naseljima Log pod Mangartom i Strmec na Predelu 2015. godine

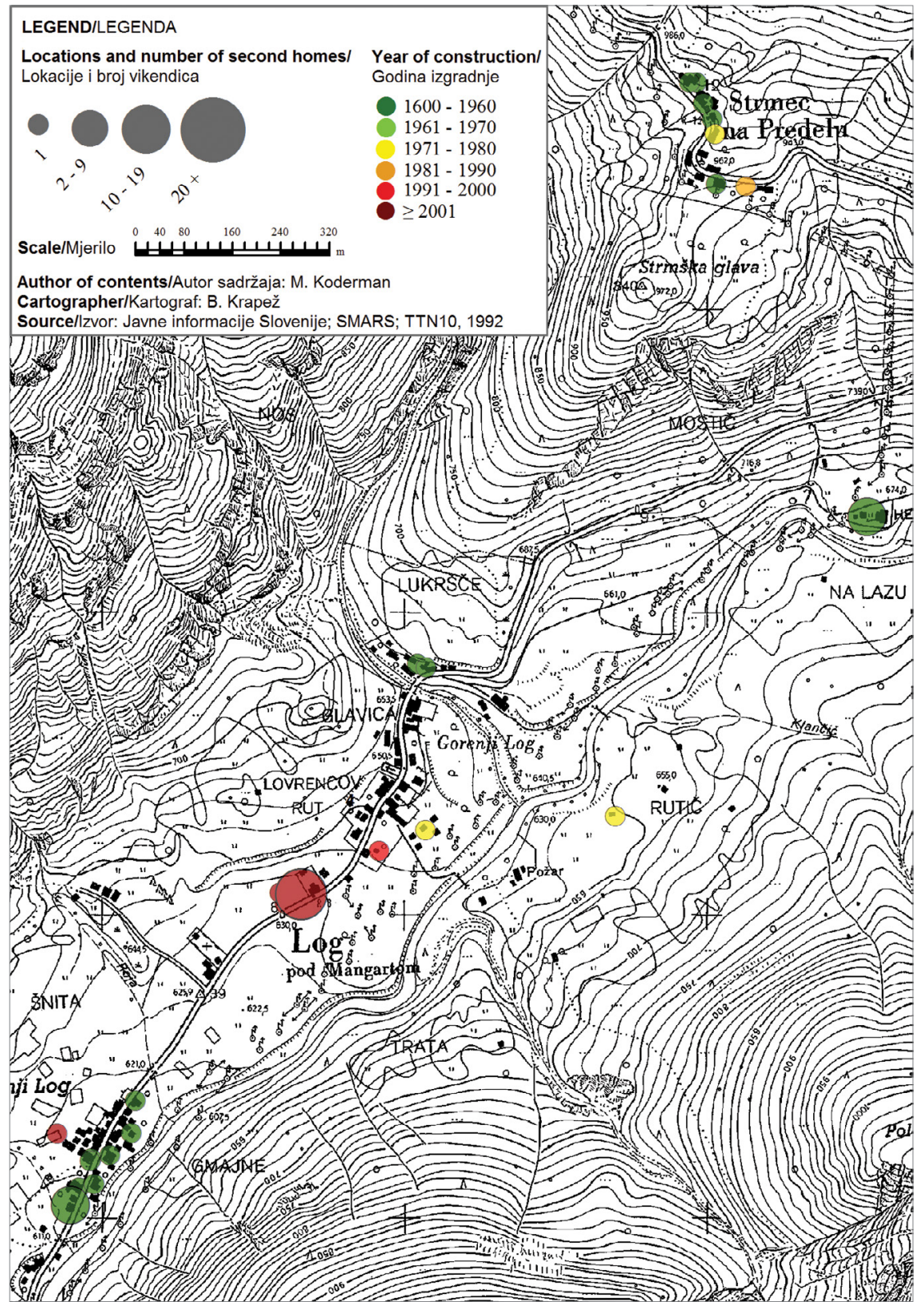


Second homes in the village of Log pod Mangartom can be found in the hamlets of Gorenji and Spodnji Log, where they are largely single-family houses, mostly built before the 1960s (there was a total of 43 second homes registered in 2015, out of which 21 were built before the Second World War). Second homes represent a constituent part of the settlement nucleus and in general do not significantly interfere with the settlement pattern, with the exception of a multi-apartment building, which was built in 2007 (shown by a brown dot in Fig. 5) and could therefore be controversial from the aspect of the TNP Act. The village of Strmec na Predelu shows a similar pattern, as second homes are located in the renovated houses within the urban nucleus of village (SMARS, 2015).

\section{Conclusion}

The paper has presented selected characteristics of second home development in the municipality of Bovec. The analysis presented some limitations in the spatial development of second homes, such as those associated with natural elements (settlement is limited to the flat terrain in the Alpine valleys), as well as administrative regulations (limited construction and renovation restrictions within TNP). Sonderegger and Bätzing (2013) exposed similar results in their research, which also included identification of (natural and cultural) obstacles for the development of second homes. The social and environmental aspect of second home enlargement is to a large extent comparable to certain cases in Scandinavian mountainous areas-in this regard, a study of Farstad and Rye (2013) has to be mentioned. The local residents and owners of second homes in several tourism-oriented areas in Scandinavia oppose the construction of new second homes and services in a similar manner to the residents of many Slovene tourism destinations, who oppose the construction of multi-apartment buildings that had already transformed traditional village nuclei of several (Alpine) settlements.

Some settlements of the municipality of Bovec took part in this process, too. However, the impact of second homes on the general appearance and ground plan of the town of Bovec can be considered as less problematic compared to some villages in traditional Alpine cultural landscape within the TNP area. As
Vikendice u selu Log pod Mangartom mogu se pronaći u zaseocima Gorenji i Spodnji Log, gdje se većinom radi o obiteljskim kućama izgrađenima prije 1960-ih godina (ukupno su 2015. godine registrirane 43 vikendice, od čega je 21 izgrađena prije Drugoga svjetskog rata). Vikendice su sastavni dio jezgre naselja i općenito ne utječu značajno na prostornu strukturu naselja, s iznimkom stambene zgrade koja je izgrađena 2007. (prikazana smeđom točkom na sl. 5) i koja bi, stoga, mogla biti kontroverzna u smislu $\mathrm{Za}$ kona o NPT. Selo Strmec na Predelu ima slič$\mathrm{nu}$ prostornu strukturu jer se vikendice nalaze $\mathrm{u}$ obnovljenim kućama unutar urbane jezgre sela (SMARS, 2015).

\section{Zaključak}

U ovom su radu predstavljene odabrane značajke razvoja vikendaštva u općini Bovec. Analizirana su neka ograničenja u prostornom razvoju vikendaštva, primjerice ona povezana s prirodnim elementima (naselje je ograničeno na ravan teren u alpskim dolinama) te administrativnim propisima (ograničena izgradnja i obnova unutar NPT). Sonderegger i Bätzing (2013) u svojem su istraživanju prikazali slične rezultate koji su također uključivali identifikaciju (prirodnih i kulturnih) prepreka za razvoj vikendica. Društveni i okolišni aspekt širenja vikendaštva u velikoj je mjeri usporediv s određenim slučajevima u skandinavskim planinskim područjima $-\mathrm{u}$ tom kontekstu valja spomenuti studiju koju su proveli Farstad i Rye (2013). Lokalno stanovništvo i vlasnici vikendica u nekoliko skandinavskih područja orijentiranih na turizam protive se izgradnji novih vikendica i usluga slično kako se stanovnici mnogih slovenskih turističkih destinacija protive izgradnji višestambenih apartmanskih zgrada namijenjenih odmoru i rekreaciji koje su već transformirale jezgru tradicionalnoga sela u nekoliko (alpskih) naselja.

Neka naselja u općini Bovec također su sudjelovala u tom procesu. Ipak, utjecaj vikendica na općeniti izgled i tlocrt grada Bovca može se smatrati manje problematičnim u usporedbi s nekim selima u tradicionalnom alpskom kulturnom pejzažu unutar područja NPT. Kao što je razvid- 
is evident from the presented statistical data and the Real Estate Registry, the prohibition on construction of second homes (or change of function of the existing buildings), implemented by the TNP Act in 1981 and 2010, has limited the construction, but failed to completely prevent it (some examples were presented in Fig. 4 and Fig. 5). Nevertheless, one can only imagine how the cultural Alpine landscape of the Julian Alps would look without the implementation of the TNP Act. The number of illegal buildings used as second homes in the municipality of Bovec is less distinct and problematic compared to some other settlements and municipalities located within the park (i.e. Bohinj, Kranjska Gora) (Koderman and Salmič, 2013; Salmič and Koderman, 2013).

Due to technical limitations (data were obtained from the Real Estate Registry), it was not possible to analyse those second homes in which the owners officially registered permanent or temporary residence due to speculative reasons (tax and social benefits). Such examples are not included in official statistics, and, of course, the impacts and effects of using such dwellings are the same as in the case of (officially registered) second homes. We could add, in a critical sense, that a more detailed analysis of this multi-faceted and complex issue would require a broader empirical study examining and further evaluating the data recorded in the censuses, the Real Estate Registry and SORS.

It can be concluded that the further development of holiday houses and apartments in the municipality of Bovec should be done in accordance with the principles of sustainable development and must therefore be carefully planned by the municipal authorities and the management of TNP. Unsupervised construction of new units or renovation and expansion of existing housing stock for holiday use, which is in practice often associated with the profitable interests of investors and other capital owners, can cause permanent and irreparable damage to the ecological, physiognomic, cultural and social environment of this mountainous region of Slovenia.

\section{Professional Terms Editing: \\ Vuk Tvrtko Opačić, PhD, Associate Professor}

Translation: Martina Batinica no iz prikazanih statističkih podataka i Registra nekretnina, zabrana izgradnje vikendica (ili promjena funkcije postojećih građevina), provedena Zakonom o NPT iz 1981. i 2010., ograničila je izgradnju, no nije ju uspjela u potpunosti spriječiti (neki su primjeri prikazani na sl. 4 i sl. 5). Ipak, možemo tek zamisliti kako bi kulturni alpski pejzaž Julijskih Alpa izgledao bez provedbe $\mathrm{Za}$ kona o NPT. Broj nezakonitih građevina koje se upotrebljavaju kao vikendice u općini Bovec nije toliko izrazit i manje je problematičan u usporedbi s nekim drugim naseljima i općinama koje se nalaze unutar parka (npr. Bohinj, Kranjska Gora) (Koderman i Salmič, 2013; Salmič i Koderman, 2013).

Zbog tehničkih ograničenja (podaci su dobiveni iz Registra nekretnina) nije bilo moguće analizirati vikendice koje su vlasnici službeno registrirali kao trajno ili privremeno boravište iz spekulativnih razloga (porez i socijalne naknade). Takvi primjeri nisu uključeni u službene statističke podatke, no, naravno, utjecaji korištenja takvih kuća jednaki su onima u slučaju (službeno registriranih) vikendica. Možemo, u kritičkom smislu, dodati da bi detaljnija analiza toga višedimenzionalnog i složenog problema zahtijevala širu empirijsku studiju koja bi proučila i dublje evaluirala podatke zabilježene u popisu, Registru nekretnina i SORS-u.

Može se zaključiti da bi se razvoj vikendaštva u općini Bovec trebao odvijati u skladu s načelima održivoga razvoja te ga stoga lokalne vlasti i uprava NPT moraju pažljivo isplanirati. „Divlja” izgradnja novih stambenih jedinica za odmor i rekreaciju ili obnova i širenje postojećega stambenog fonda namijenjena za odmor i rekreaciju, što je u praksi često povezano s dobiti ulagača i drugih vlasnika kapitala, može uzrokovati trajnu i nepopravljivu štetu ekološkom, fizionomskom, kulturnom i društvenom okruženju ove planinske slovenske regije.

Stručna redaktura:

izv. prof. dr. sc. Vuk Tvrtko Opačić

Prijevod: Martina Batinica
Second homes in the Slovenian Alps with special emphasis on the Municipality of Bovec

Vikendice u slovenskim

Alpama s posebnim naglaskom na općinu Bovec

\section{Note}

Napomena 
GLASNIK

81/1, 61-81 (2019.)

\section{Literature} Literatura

Sources

Izvori
Bajuk Senčar, T., 2005: Kultura turizma: antropološki pogledi na razvoj Bohinja, ZRC, Ljubljana.

Farstad, M, Rye, J. F., 2013: Second home owners, locals and their perspectives on rural development, Journal of Rural Studies 30 (1), 41-51, DOI: http://dx. doi.org/10.1016/j.jrurstud.2012.11.007.

Flognfeldt, T., Tjørve, E., 2013: The Shift from Hotels and Lodges to Second-Home Villages in Mountain-Resort Accommodation, Scandinavian Journal of Hospitality and Tourism 13 (4), 332-352, DOI: https://doi.org/10.1080/ 15022250.2013 .862440 .

Gosar, A., 1987: Počitniška bivališča v alpskem svetu in Bohinjski zbornik, Municipality board, Radovljica, 19-23.

Gosar, A., 1988: Počitniške hiše kot element transformacije slovenskih alpskih pokrajin (PhD thesis), Filozofska fakulteta Univerze v Ljubljani, Ljubljana.

Hall, M.C., Müller, D. K., 2004: Tourism, Mobility and Second Homes: Between Elite Landscape and Common Ground, Channel View Publications, Clevedon.

Hall, M.C., Müller, D. K., Saarinen, J., 2008: Nordic Tourism: Issues and Cases, Channel View Publications, Clevedon.
Kalan, M., 1983: Počitniške hiše v Bohinju (Graduation thesis), Filozofska fakulteta Univerze v Ljubljani, Ljubljana.

Kaltenborn, B. P., Andersen, O., Nellemann, C., 2009: Amenity development in the Norwegian mountains: Effects of second home owner environmental attitudes on preferences for alternative development options, Landscape and urban planning 91 (4), 195-201, DOI http://dx.doi.org/10.1016/j.landurbplan.2009.01.001.

Koderman, M., 2014: Spatial Analysis of Second Homes in the Municipality of Piran, Academica turistica 7 (2), 179-191.

Koderman, M., 2017: Second Homes in Protected Areas of Slovenia - The Case of the Triglav National Park, in: Tourism in Protected Areas of Nature in Serbia and Slovenia (eds. Filipović D. et al.), University of Belgrade - Faculty of Geography, Belgrade, 87-100.

Koderman, M., Salmič, S., 2013: Prebivati ob "jezeru bliz' Triglava": Prostorska analiza počitniških bivališč v občini Bohinj, in: Gorenjska v obdobju glokalizacije (eds: Mrak, I. et al.), Znanstvena založba Filozofske fakultete Univerze v Ljubljani, Ljubljana, 111-126.
Komac, B., Zorn, M., Kušar, D., 2012: New possibilities for assessing the damage caused by natural disasters in Slovenia - The case of the Real Estate Record, Geografski vestnik 84 (1), 113-127.

Nared, J., Razpotnik Visković, N., Komac, B., 2015: The Alps: a physical geography, political, and program framework, Acta geographica Slovenica 55 (1), 165172, DOI: http://dx.doi.org/10.3986/ AGS.1970.

Salmič, S., Koderman, M., 2013: Prostorska analiza počitniških bivališč v Občin Kranjska Gora, Geografski vestnik 85 (1), 9-24.

Sonderegger, R., Bätzing,W., 2013: Second homes in the Alpine Region, Journal of Alpine Research 101 (1), 1-14, DOI http://dx.doi.org/10.4000/rga.2511.

Vojvoda, M., 1965: Razvoj kulturne pokrajine v Bohinju (PhD thesis), Filozofska fakulteta Univerze v Ljubljani, Ljubljana.

Vranješ, M., 2005: Zelena puščava: kulturna krajina iz "domačinskega zornega kota”, Etnolog 15 (1), 281-301.

Vranješ, M., 2008: Prostor, teritorij, kraj: produkcije lokalnosti v Trenti in na Soči Založba Annales, Koper.

TNP, 2012: Analysis of settlement status. Starting point for the Triglav National Park Management Plan 2012-2022/Analiza stanja poselitve. Izhodišăa za Načrt upravljanja Triglavskega narodnega parka 2012-2022, http://www.tnp.si/images/uploads/analiza_poselitve.pdf (12. 7.2016).

Bureau of SR of Slovenia for statistics/Zavod SR Slovenije za statistiko, 1971: Census of population and dwellings, 1971, Book 6: For rest and recreation, results by settlements and municipalities 1971/Popis prebivalstva in stanovanj v letu 1971, Knjiga 6: Za pocitek in rekreacijo, rezultati po naseljib in občinah 1971, Ljubljana.

Bureau of SR of Slovenia for statistics/Zavod SR Slovenije za statistiko, 1981: Census of population, households and dwellings in SR Slovenia, 31. 3. 1981, Survey results 323/Popis prebivalstva, gospodinjstev in stanovanj v Socialistični Republiki Sloveniji, 31. 3. 1981, Rezultati raziskovanj 323, Ljubljana.

Statistical Office of the Republic of Slovenia/Statistični urad Republike Slovenije, 1991: Census of dwellings, 1991, Statistical information, dwellings for rest and recreation 185/ Popis stanovanj, 1991, Statistične informacije, Stanovanja za počitek in rekreacijo 185, Ljubljana.

Statistical Office of the Republic of Slovenia/Statistični urad Republike Slovenije, 2002: Census of dwellings, 2002: Dwellings for rest and recreation/Popis stvab in stanovanj, 2002: Stanovanja za počitek in rekreacijo, 2002.

Miklič, E., 2016: Spremembe v številu počitniških bivališč v občini Bovec (oral source), 22.1.2016.

Ordinance on the municipal spatial plan of Bovec/Odlok o obcinskem prostorskem načrtu OPN Bovec: Uradni list RS 119/2008.

SMARS, 2015: Surveying and Mapping Authority of the Republic of Slovenia, Real Estate Register, the database of the municipality of Bovec.

Statistical Office of the Republic of Slovenia/Statistični urad Republike Slovenije (SORS), 2011a: Accommodation for holiday purposes or secondary use by type of building and number of rooms/Stanovanja za počitniški namen ali sekundarno rabo po vrsti stavbe in številu sob, http://pxweb.stat.si/pxweb/Dialog/varval.asp?ma=0861150S\&ti=\&path=../ Database/Dem_soc/08_zivljenjska_raven/25_STANOVANJA/02_08611-stanovanja_OBC/\&lang=2, (4.12.2017). 
Statistical Office of the Republic of Slovenia/Statistični urad Republike Slovenije (SORS), 2011b: Number of dwellings by population/ Število stanovanj po naseljenosti, http://pxweb.stat.si/pxweb/Dialog/varval.asp?ma=0871201S\&ti=\&path=../Database/Dem soc/08_zivljenjska_raven/25_STANOVANJA/04_08712-stanovanja_NAS/\&lang=2, (12.7.2017).

Statistical Office of the Republic of Slovenia/Statistični urad Republike Slovenije (SORS), 2011c: Holiday apartments, municipality of Bovec, settlements, internal data.

The Triglav National Park Act, 1981: Uradni list SRS 17/1981.

The Triglav National Park Act, 2010: Uradni list RS 52/2010.

Miha Koderman

miha.koderman@fhs.upr.si.

$\mathrm{PhD}$, Associate Professor, University of Primorska, Faculty of Humanities, Department of Geography, Titov trg 5,

SI-6000 Koper, Slovenia

Marko Pavlič

marko.pavlic@gov.si

Adviser, Statistical Office of the Republic of Slovenia, Department for Environment and Energy Statistics, Litostrojska cesta 54,

SI-1000 Ljubljana, Slovenia
M. Koderman M. Pavlič

Second homes in the Slovenian Alps with special emphasis on the Municipality of Bovec

Vikendice u slovenskim

Alpama s posebnim naglaskom na općinu Bovec
Authors

Autori 